\title{
A Comparison between Generative Learning Model and CORE Learning Model: The Influence on Learners' Higher Order Thinking Skill
}

\author{
Chalia Chistella, Hadi Soekamto \\ ${ }^{1,2}$ Faculty of Social Sciences - State University of Malang - Indonesia
}

\begin{abstract}
Generative and Connecting, Organizing, Reflecting, Extending (CORE) are two kinds of learning model thatcan improve learners' higher order thinking skill (HOTS). The purpose of this study was to point out the best model to improve learners' HOTS. For this purpose, a quasi-experiment was done in 7 Malang Indonesia Senior High School. Twogroups of tenth grades learnerswere selected by random sampling method. Generative learning model was applied to the first group, while CORE learning model was applied to the second group. Learners' HOTS were measured by the test which made based on HOTS indicators. Before starting the program, each group took a pre-test. The program lasted for three weeks, and four hours each week; and at the end of the program post-test works were taken from the candidates. The hypothesis was tested using independent sample $t$-test using SPSS 16.00 for windows with probability of significance value of 0.05.The results of the research shown that there was a significant difference between the gain score points of the experimental groups $(P<.05)$.The results also showed that the average of learners' HOTS points withgenerative learning model washigher than the other group.It was observed that this paper previously uncovered a role for (1) Barbara L. Grabowski (2014) that generative learning model can increase higher order thinking skill, and (2) Robert C. Calfee (2004) that CORE can increase higher order thinking skill. This manuscript builds on our prior study to compare about both models, and focus on the effects on higher order thinking skill.
\end{abstract}

Keywords: generative learning model, CORE learning model, higher order thinking skill

\section{Introduction}

In $21^{\text {st }}$ century, higher order thinking skill (HOTS) is being an essential issue for learners. This issue is triggered by increasingly complex life and work environments (Autor D. H, et all, 2003; Duncan, 2009; Faulkner J. and Latham G, 2016). To prepare learners for this competitiveness, higher order thinking skill is being a focus. Higher order thinking skill can be learned like most skills through innovative learning. Thus, a variety of learning model innovations have strived to develop the skill (Alismail \& McGuire, 2015; Ledward \& Hirata, 2011). Generative learning model and Connecting, Organizing, Reflecting, Extending (CORE) learning model are examples of that innovations.

Generative learning model and Connecting, Organizing, Reflecting, Extending (CORE) learning model are the examples of learning model innovations that can improve learner's higher order thinking skill. Generative learning model is a process of learning that emphasizes on integration of learner's new knowledge and existing knowledge (Osborn and Wittrock, 1983). Similar to generative learning model, CORE learning model also emphasize the learning of learners with knowledge on construction of organizing prior knowledge and new knowledge (Calfee, 2004). So, both of these models are equivalent because both of these models emphasizes learning by organizing existing knowledge and new knowledge. Thus, generative learning model and CORE learning model deserves to be compared.

\subsection{Higher Order Thinking Skill}

Higher order thinking skill essentially means thinking that takes place at the highest level in a cognitive process (Krulik and Rudnik, 1993). Higher order thinking happens when someone took the existing information and the new information, thenconnected or reorganize the informations.Finally, someone expand this organized information to achieving goals or finding answers (Nitko and Brookhart, 2011; Thomas and Thorne, 2009; Heong's, 2011). This ability requires more practices in order to thrive the skill. There are several factors affecting higher order thinking skill, including intelligentsia, environment, and experience (Budsankom et al., 2015; Kane, et al., 2004; Kim, 2005; Horan, 2007; Ari and Eliassy, 2003; Bong, 2005; Patrick et al., 2007; Nelson and Debacker, 2008; Dorman, 2009; Baeten et al., 2013; Newmann, 2006). Learner's higher order thinking skill can be measured by several indicators i.e., analysing (C4), evaluating (C5), and creating (C6)(Anderson and Krathwohl, 2001; Marzano, 1998). 


\subsection{Generative Learning Model}

Generative learning model is a very active process for learners. Learners are required to connect new information and existing information they had (Anderman, 2010; Grabowski et al., 2014; Osborn and Wittrock, 1983). They created their own concept with the knowledge that a new concept has been known (Kish, 2008). This learning model has advantages among learners, i.e., active in learning and memory, stimulates curiosity learners, and learners can make the hypothesis of a problem (Grabowski et al., 2014; Sutarman and Suwarsono, 2003). In addition to these advantages, this learning model also has some disadvantages including the tendency of misconception and takes a long time (Sutarman and Suwarsono, 2003). There are several stages in generative learning models include (1) exploration, (2) focusing, (3) challenge, and (4) the application of the concept (Slavin, 1990; Sutarman and Suwarsono, 2003).

\subsection{CORE Learning Model}

CORE learning model is one of the learning process that demands the learners to be active in learning. The learning model was first developed by Calfee in 1998. Calfee (2004) revealed that the intended learning CORE model is a model of learning which expect learners to be able to construct their own knowledge with the stages of (1) connecting, (2) organizing, (3) the reflecting, and (4) extending. This model encourages learners to able exchange information with other learners to find the misconception happened and shape it into a new knowledge units (Calfee, 2004). While the weakness of this model is the tendency of misconceptions and free rider.

\section{PURPOSE}

The purpose of this study are to find out whether there is a difference of learners'HOTS using generative learning model and CORE learning model and to point out the best model to improve learners' HOTS. Thus, the hypothesis below were tested in the framework of this general aim based on HOTS indicators.

Hypothesis 1: There is no significant difference between the pre-test and post-test points of the experimental group to whom generative learning model was applied.

Hypothesis 2: There is no significant difference between the pre-test and post-test points of the experimental group to whom CORE learning model was applied.

Hypothesis 3: There is no significant difference between the gain score points(the differences between pretest and posttest) of the first experimental group to whom generative learning model is applied and the second experimental group to whom CORE learning model is applied.

\section{Method}

This study is a quantitative research to determine the differences between generative learning model and CORE learning model of teaching geography. The sample of the study consisted of 56 first year learners at a social science program at 7 Malang Senior High School, during the first semester of the 2016-2017 academic years. The participants in the study were 26 males $(46.4 \%)$ and 30 females (53.6\%). Age levels ofthe participants ranged from 15 to 17 . For the sample of the research 28 students (16 female and 12 male) were chosen to form the first experimental group and 28 students ( 14 female and 14 male) at the same age levels were randomly selected to form the second experimental group. The groups were formed heterogeneous by the researchers.

Before starting the program, each group took the pre-test. The first group was taught using generative learning model and the second group was taught using CORE learning model. The program lasted for three weeks, and four hours each week; and at the end of the program post-test works were taken from the candidates. Then, after the program, each group took the post-test. In the schematic design of this study as follows.

\section{Experimental Design}

\begin{tabular}{llll}
\hline $\mathrm{O}_{1}$ & $\mathrm{E}_{3}$ & $\mathrm{X}_{1}$ & $\mathrm{O}_{2}$ \\
$\mathrm{O}_{1}$ & $\mathrm{E}_{4}$ & $\mathrm{X}_{2}$ & $\mathrm{O}_{2}$ \\
\hline
\end{tabular}

\section{Description:}

$\mathrm{O}_{1}$ : Pre-test

$\mathrm{E}_{1} \quad: 1^{\text {st }}$ experimental group

$\mathrm{E}_{2}: 2^{\text {nd }}$ experimental group

$\mathrm{X}_{1}$ : Generative learning model was applied

$\mathrm{X}_{2}$ : CORE learning model was applied

$\mathrm{O}_{2} \quad$ : Post-test 
Research instrument used in the study is a test using the five subjective questions given after the study. The making of the test was based on the indicators of higher order thinking skills. Before using the instrument, the instrument was tested using validity and reliability test using the SPSS 16.0 for windows.

The data collected in the study was tested with quantitative statistics inferential. Hypothesis testing was based on the results of the calculation using the SPSS 16.0 for windows. The hypothesis was tested using Independent sample t-test. If the value of the probability of significance $(\mathrm{P}<.05)$, then the hypothesis is rejected.

\section{Results}

As shown in this research, higher order thinking skill was measured by five subjective questions based on indicators of higher order thinking skill.In this section, the findings acquired as a result of the research have been analysed according to the related hypotheses.

Hypothesis 1: There is no significant difference between the pre-test and post-test points of the experimental group to whom generative learning model was applied.

According to the result of the t-test, carried out between the pre-test and post-test points of the experimental group to whom the generative learning model was applied; it has been seen that there is a significant difference;

$[t(54)=-6.11 p<.05]$ in the component ofanalysing skill,

$[t(54)=-9.3 p<.05]$ in the component of evaluating skill,

$[t(54)=-16.47 p<.05]$ in the component of creating skill,

therefore hypothesis 1 has been rejected. The generative learning model improves learners' HOTS effectively.

Hypothesis 2: There is no significant difference between the pre-test and post-test points of the experimental group to whom CORE learning model was applied.

According to the result of the t-test, carried out between the pre-test and post-test points of the experimental group to whom the CORE learning model was applied; it has been seen that there is a significant difference;

$[t(54)=-12.90 p<.05]$ in the component ofanalysing skill,

$[t(54)=-15.91 p<.05]$ in the component of evaluating skill,

$[t(54)=-33.14 p<.05]$ in the component of creating skill,

therefore hypothesis 2 has been rejected. The CORE learning model improves learners' HOTS effectively. In this situation, it will be more appropriate to make a comparisonbetween the first group and the second group.

Hypothesis 3: There is no significant difference between the gainscore pointsof the first experimental group to whom generative learning model is applied and the second experimental group to whom CORE learning model is applied. The results of the t-test carried out between the gain score of the first experimental group and the second experiment group of each learning models, no significant difference has been found

$[t(54)=1.39 p>.05]$ in the component of in analysing skill,

$[\mathrm{t}(54)=1.70 \mathrm{p}>.05]$ in the component of in evaluating skill,

$[\mathrm{t}(54)=2.44 \mathrm{p}<.05]$ in the component of creating skill,

In this case, hypothesis 3 was rejected for the component of creating skill,but accepted for the component of in analysing skill and the component of in evaluating skill.There was

more increase in the arithmetical mean of the first experimental group than the second experimental group.

The data acquired has shown that the generative learning model has improved learners' higher order thinking skill of thetenth grade learners from the social science department in 7 Malang Senior High School more than CORE learning model.

\section{Discussion}

In this research the effects of generative learning model and CORE learning model on learners' higher order thinking skill were searched. For this reason, two experimental groups were formed. Whereas generative learning model was applied to the first experimental group, while CORE learning model was applied to the second experimental group.

The data of this research has indicated that generative learning model and CORE learning model improved learners' HOTS.There has been a result in favour of the first experimental group of learners' especially in the component of creating skill.Application of generative learning model for three weeks has improved the creating skill of learners considerably. In fact, when the point increases were analysing skill and evaluating skill, itwas again in favour of the experimental group. If the program had lasted more thanthree weeks, the results between groups wouldhave been different.

Based on data analysis, there was a significant difference between the pre-test and post-test points of the first experimental group to whom generative learning model was applied. There was also a significant difference between the pre-test and post-test points of the second experimental group to whom CORE learning model was applied. Both models had a positive impact in learners' HOTS. These finding is supported by the 
previous researches as follows: (1) The findings of Grabowski (2014) that generative learning model can increase gains in recall, comprehension, and higher order thinking skill as well as improvement in self-regulated learning skill; (2) The findings of Calfee (2004) that CORE learning model emphasized learners to exchange information with other learners to find the misconception happened and shape it into a new knowledge units. But there were no previous researches compare these models. The result shown that learners' higher order thinking skill with generative learning model and CORE learning model increased because these models emphasized construction of learners' new information and existing information (Brown \&Lehn, 1980; Calfee, 2004; MacGillivray, et al., 2010; Grabowsi, et al., 2014; Maknun, 2015).

However, generative learning model had better impact of higher order thinking skill because this model give a new concept to learners after each learners made a hypothesis of problem. This step is very effective to encourage learners' enthusiasm on new concept given by teacher to strengthen their hypothesis. CORE learning model has lower impact of higher order thinking skill because the new concepts were given before learners face the problem and make their hypothesis of problem. This influence learners lose their enthusiasm and being a free rider in a group discussion.

The weakness of generative learning model mostly resemble to CORE learning model, such as the tendency of misconception, free rider, and takes a long time. The weakness of both models should be handled by a prepared-well lesson plans to ensure the time effectiveness (Velmahos et al.,2004; Clark \& Elen, 2006). Besides, the teacher should create an atmosphere that can achieve the goal of effective and efficient learning, not only the interaction between learners and teachers, but also the interaction with learning resources that exist in the environment around the learners (Fatchan, 2015).

\section{Conclusion}

Based on data analysis, we can conclude that there is a significant difference between learners' HOTS using generative learning model and CORE learning model, especially in the component of creating skill. Learners'HOTS with generative learning model is higher than CORE learning model.

Future researchers should understand the weakness and the strength of generative learning model and CORE learning model well. The weakness of both models should be handled by a prepared-well lesson plans to ensure the time effectiveness.

A number of limitations need to be considered in interpreting the findings of this study. This study included only the tenth grade learners from the social science department in 7 Malang Senior High School. A more comprehensive study including the other disciplines and/or across disciplines will contribute to our understanding of the relationship attitudes as well as their main effect on achievement.

\section{Acknowledgements}

We would like to thank the editor and anonymous referees for their helpful advices and suggestions on early drafts of the paper. We would also like to Cakti Indra Gunawan, M.M., Ph.D for the financial support.

\section{References}

[1]. Alismail, H. A. \& McGuire, P. (2015). 21st Century Standards and Curriculum: Current Research and Practice. Journal of Education and Practice. Department Curriculum and Instruction, School of Education, University of Colorado Colorado Springs. Vol 6(6), 150-154.

[2]. Anderman, E. M. (2010). Reflection on Wittrock's Generative Model of Learning: A Motivation Perspective. Educational Psycologist Journal. America: Routledge Taylor \& Francis Group. Vol 45(1), 55-60.

[3]. Anderson, L. \& Krathwohl, D. (2001). A Taxonomy for Learning, Teaching, and Assesing: A Revision of Bloom's Taxonomy of Educational Objectives. A Bridged Eddition: Addison Wesley Longman, Inc.

[4]. Ari R.B. \& Eliassy, L. (2003). The Differential Effects of the Learning Environment on Student Achievement Motivation: A Comparison between Frontal and Complex Instruction Strategies. Social Behaviour Personality: An International Journal. Vol 31(2), 143-166.

[5]. Autor, D. H., Levy, F \& Murnane, R. (2003). The Skill Content of Recent Technological Change: An Empirical Exploration. Quarterly Journal of Economics, Vol 118(1), 157-205.

[6]. Baeten, M, Dochy, F, \& Struyven, K. (2013). The Effects of Different Learning Environments on Students' Motivation for Learning and Their Achievement. British Journal of Educational Psychology. Vol 83, 484-501

[7]. Bong, M. (2005). Within-Grade Changes in Korean Girls' Motivation and Perceptions of the Learning Environment across Domains and Achievement Levels. Journal of Educational Psychology. Vol 97(4), 656-672

[8]. Brown, J. S., \&Lehn, K. (1980). Repair theory: A generative theory of bugs in procedural skills. Cognitive Science, Vol 4, $379-426$.

[9]. Budsankom, P. (2015). Factors Affecting Higher Order Thinking Skills of Students: A Meta-Analytic Structural Equation Modeling Study. Educational Recearch and Review Journal. Vol 10(19), 2639-2652.

[10]. Calfee \& Miller. (2004). Making Thinking Visible: A Method to Encourage Science Writing in Upper Elementary Grade. Riverside: University of California.

[11]. Clark, R. E., \& Elen, J. 2006. Handling Complexity in Learning Environments: Research and Theory. Oxford: Elsevier Science Limited.

[12]. Crawford, T.N, Cohen, P, Midlarsky, E, \& Brook, J.S. (2001). Internalizing Symptoms in Adolescents: Gender Differences in Vulnerability to Parental Distress and Discord Authors. Journal of Research and Adolescence, Vol 11(1), 95-118.

[13]. Dorman, J. P. (2009). Associations between Psychosocial Environment and Outcomes in Technology-Rich Classrooms in Australian Secondary Schools. Research in Education. Vol 82(1). 
[14]. Duncan, A. (2009). Teacher Preparation: Reforming the Uncertain Profession. [Online] Available:

[15]. http://www.ed.gov/news/speeches/teacher-preparation-reforming-uncertain-profession. (November 25, 2016).

[16]. Fatchan, A, Amirudin, A, \& Soekamto, Hadi. (2015). Education Model of "Bandongan" for Farmers Society Agriculture Skill Training in the Background Socioculture "Pesantren" in East Java. Mediterranean Journal of Social Sciences, Vol 6(5), 515-523.

[17]. Faulkner, J. \& Latham, G. (2016). Adventurous Lives: Teacher Qualities for 21st Century Learning. Australian Journal of Teacher Education. Vol 41(4), 137-150.

[18]. Grabowski, et all. (2014). Generative Learning: Principles and Implications for Making Meaning. Pennsylvania: University of Pennsylvania.

[19]. Heong, Y.M, et al. (2011). The Level of Marzano Higher Order Thinking Skillss among Technical Education Students. International Journal of Social Science and Humanity. Vol 1(2), 121-125.

[20]. Horan R. (2007). The Relationship between Creativity and Intelligence: A Combined Yogic- Scientific Approach. Creativity Research Journal. Vol 19, 179-202.

[21]. Johnson, S.P. (2003). The Nature of Cognitive Development. TRENDS in Cognitive Sciences. Vol 7(3), 102-104

[22]. Kane, et al. (2004). The Generality of Working Memory Capacity: A Latent Variable Approach to Verbal and Visuospatial Memory Span and Reasoning. Journal of Experimental Psychology: General, Vol 133, 189-217.

[23]. Kim, K. (2005). Can only intelligent people be creative? A meta-analysis. Journal of Secondary Gifted Education, Vol 16, 57-66.

[24]. Kish, M.H.Z. (2008). How to UseVignettes in An Online Environment to Expand Higher Order Thinking in Adults. In L. Tomei (Ed.), Adapting Information and Communication Technologies for Effective Education. Hershey, PA: Information Science Reference.

[25]. Krulik. S. \& Rudnick, A.J. (1993). Reasoning and Problem Solving: A Handbook for Elementary School Teachers. USA: Allyn and Bacon A Division of Simon and Schuster, Inc.

[26]. Ledward, B. C. \& Hirata, D. (2011). An Overview of 21st Century Skills. Summary of 21st Century Skills for Students and Teachers, by Pacific Policy Research Center. Honolulu: Kamehameha Schools-Research \& Evaluation.

[27]. MacGillivray, L, Ardell, A.M, \& Curwen, M.S. (2010). Supporting the Literacy Development of Children Living in Homeless Shelters. Education Faculty Articles and Research, Vol63(5), 384-392.

[28]. Maknun, J. (2015). The Implementation of Generative Learning Model on Physics Lesson to Increase Mastery Concepts and Generic Science Skills of Vocational Students. American Journal of Educational Research, Vol 3(6), 742-748.

[29]. Marzano, R. J. (1998). A Theory-Based Meta-Analysis of Research on Instruction. Aurora, CO: McREL.

[30]. Nair, P. \& Fielding, R. (2007). A Comfortable Truth: Well-Planned Classrooms Make a Difference. [Online] Available: https://www.edutopia.org/comfortable-truth. (Maret 1, 2017)

[31]. Nelson, R.M, Debacker, T.K. (2008). Achievement Motivation in Adolescents: The Role of Peer Climate and Best Friends. Journal of Experimental Education. 76(2), 170-189.

[32]. Newmann, F.M. (2006). Higher Order Thinking In Teaching Social Studies: A Rationale for the Assessment of Classroom Thoughtfulness. Journal of Curriculum Studies. Vol 22 (1), 41-56.

[33]. Nitko, A.J. \& Brookhart, S.M. (2011). Educational Assessment of Student (6th ed). Boston: Pearson Education.

[34]. Osborne, R.J. \& Wittrock, M.C. (1983). The Generative Learning Model and its Implications for Science Education. Studies in Science Education 12

[35]. Pappas, C. (2014). Activity Theory as a Framework for Analyzing CBT and E-Learning Environments. Educational Technology, Vol 36-42.

[36]. Patrick H, Ryan A, Kaplan A. (2007). Early Adolescents' Perceptions of the Classroom Social Environment, Motivational Beliefs, and Engagement. Journal of Educational Psychology. 99(1), 83-88.

[37]. Slavin, R. (1990). Cooperative Learning: Theory, Research and Practice. Englewood Cliff, NJ: Prentice.

[38]. Sutarman \& Suwarsono. (2003). Implementation of Generatif Learning Model with Constructivism Based to Improve Student 3rd Skill SLTP 17 Malang. Indonesia: State University of Malang.

[39]. Thomas, A. \& Thorne, G. (2009). How to Increase Higher Order Thinking, Metarie, LA: Center for Development and Learning.

[40]. Velmahos, G. C., Toutouzas, K. G., Sillin, L. F., Chan, L., Clark, R. E., Theodorou, D., \& Maupin, F. (2004). Cognitive Task Analysis for Teaching Technical Skills inan Inanimate Surgical Skills Laboratory. The American Journal of Surgery. Vol.18 (114119). 